\title{
Characteristics of Polycyclic Aromatic Hydrocarbons (PAHs) and Common Air Pollutants at Wajima, a Remote Background Site in Japan
}

\author{
Xuan Zhang ${ }^{1}$, Lulu Zhang ${ }^{1}$, Lu Yang ${ }^{1}$, Quanyu Zhou ${ }^{1}{ }^{\circledR}$, Wanli Xing ${ }^{1}$, Akira Toriba ${ }^{2}$, \\ Kazuichi Hayakawa $^{3}$, Yongjie Wei ${ }^{4, *}$ and Ning Tang ${ }^{2,3, *(1)}$ \\ 1 Graduate School of Medical Sciences, Kanazawa University, Kakuma-machi, Kanazawa 920-1192, Japan; \\ zhangxuan@stu.kanazawa-u.ac.jp (X.Z.); zhang-lulu@stu.kanazawa-u.ac.jp (L.Z.); \\ veronicayl@stu.kanazawa-u.ac.jp (L.Y.); zhouquanyu@stu.kanazawa-u.ac.jp (Q.Z.); \\ xingwanli@stu.kanazawa-u.ac.jp (W.X.) \\ 2 Institute of Medical, Pharmaceutical and Health Sciences, Kanazawa University, Kakuma-machi, \\ Kanazawa 920-1192, Japan; toriba@p.kanazawa-u.ac.jp \\ 3 Institute of Nature and Environmental Technology, Kanazawa University, Kakuma- machi, \\ Kanazawa 920-1192, Japan; hayakawa@p.kanazawa-u.ac.jp \\ 4 State Key Laboratory of Environmental Criteria and Risk Assessment, Chinese Research Academy of \\ Environment Sciences, Beijing 100012, China \\ * Correspondence: weiyj@craes.org.cn (Y.W.); n_tang@staff.kanazawa-u.ac.jp (N.T.); Tel.: +81-76-234-4455 (N.T.)
}

Received: 23 December 2019; Accepted: 31 January 2020; Published: 4 February 2020

\begin{abstract}
Background: Background sites are mainly affected by long-range-transported air pollutants, resulting in potential adverse effects on local atmospheric environments. A 4-5 year observational study was conducted to illustrate the air pollution profile at the Kanazawa University Wajima air monitoring station (KUWAMS), an ideal remote background site in Japan. Methods: Nine polycyclic aromatic hydrocarbons (PAHs) in the particulate phase and various air pollutants were continuously monitored for 4-5 years. Diagnostic ratios of PAHs and back-trajectory analysis were applied to trace the possible sources of the air pollutants collected at the sampling site. Results: The atmospheric concentration of PAHs in the atmosphere at the site decreased from 2014 to 2019, benefit from the predominant air pollution control policy in China and Japan. Common air pollutants including sulfur dioxide $\left(\mathrm{SO}_{2}\right)$, nitrogen oxides $\left(\mathrm{NO}_{\mathrm{x}}\right)$, ozone, methane $\left(\mathrm{CH}_{4}\right)$, and non-methane hydrocarbon (NMHC) were detected in low concentrations from 2016 to 2019, while ozone $\left(\mathrm{O}_{3}\right)$ and particulate matter $\left(\mathrm{PM}_{2.5}, \mathrm{PM}\right.$ with a diameter less than $\left.2.5 \mu \mathrm{m}\right)$ were present in high levels that exceeded the Japanese standards. Most air pollutants peaked in spring and showed evident diurnal variations in spring and summer. Conclusions: This is the first study to clarify the atmospheric behaviors of multiple air pollutants at a background site in Japan. Significant external air pollutant impact and unneglectable air pollution were demonstrated at KUWAMS, indicating the importance of studying atmospheric pollution at remote sites.
\end{abstract}

Keywords: air pollution; long-range transport; trace gas; ozone; $\mathrm{PM}_{2.5}$

\section{Introduction}

As a global problem, air pollution causes adverse effects in many parts of the world [1-5]. According to the World Health Organization (WHO), approximately $90 \%$ of the world's population lives in locations with severely polluted air [6].

Particulate matter $(\mathrm{PM})$, ground-level ozone $\left(\mathrm{O}_{3}\right)$, sulfur dioxide $\left(\mathrm{SO}_{2}\right)$, and nitrogen dioxide $\left(\mathrm{NO}_{2}\right)$ are listed as criteria pollutants for determination of the air quality indexes of many countries 
and organizations, such as WHO, China, United States, and the European Union. Due to their wide dispersion and great human health risk, many epidemiological researches have been conducted to clarify the exposure-response relationship [7-10]. PM consists of solid and liquid particles suspended in the air and represents the sum of a variety of complex pollutants. Polycyclic aromatic hydrocarbons (PAHs), as components of PM, are a group of persistent organic pollutants with two or more fused benzenoid rings. Some PAHs are well known for their carcinogenicity and mutagenicity and therefore pose a serious threat to human health [11-13]. $\mathrm{SO}_{2}$ is mainly emitted from sulfur-containing fossil fuel combustion. Once produced, $\mathrm{SO}_{2}$ is easily oxidized to sulfuric acid or sulfate aerosols, which can induce acid deposition. Exposure to $\mathrm{SO}_{2}$ affects the respiratory system $[10,14]$ and causes irritation of the eyes [15]. Nitrogen oxides $\left(\mathrm{NO}_{\mathrm{x}}: \mathrm{NO}_{2}\right.$ and $\left.\mathrm{NO}\right)$ originate from primary sources like fuel burning. $\mathrm{NO}_{x}$ plays important roles in the formation of photochemical smog (precursor of $\mathrm{O}_{3}$ ) and acid rain. Exposure to $\mathrm{NO}_{2}$ can increase symptoms of bronchitis and asthma, as well as lead to respiratory infections and reduced lung function and growth [10]. Stratospheric $\mathrm{O}_{3}$ can protect humans from ultraviolet exposure, but elevated tropospheric $\mathrm{O}_{3}$ is a major and active photochemical oxidant that is one of the predominant components of photochemical smog and a key pollutant linked to breathing problems, asthma, reduced lung function, and respiratory diseases $[10,16]$. Methane $\left(\mathrm{CH}_{4}\right)$ is a vital greenhouse gas, and non-methane hydrocarbons (NMHC) are significant precursors of $\mathrm{O}_{3}$.

Generally, urban areas suffer mostly from air pollution due to the presence of extensive anthropogenic sources, such as industrial activity $[9,17]$ and vehicle emissions [18]. However, studies and observations have shown that air pollutants derived from heavy-polluted areas have unignorable effects on remote background sites through regional or continental transport from polluted sites [19-23]. The influence of transported pollutants is subject to several factors, such as potential chemical reactions during transport or at the recipient location [24-26], which complicate the effects and cause new potential adverse effects on the atmospheric environment of background areas. Local meteorological conditions can also impact the atmospheric behaviors of transported air pollutants [21]. Therefore, it is important to understand the air pollution profile in remote areas acting as a receptor of transported air pollutants to comprehensively evaluate the health effects of air pollution.

According to different atmospheric lifetimes, air pollutants can be regionally or continentally transported in air masses. Based on our previous research, PAHs detected at an ideal background site, Kanazawa University Wajima Air Monitoring Station (KUWAMS), were transported from northeastern China in the cold season and domestic Japan in the warm season and exhibited certain variations over time $[19,21,27,28]$. Additionally, it is of interest to determine the atmospheric behaviors of other air pollutants and illustrate the evolution of air masses from the Asian continent to Japan and the contribution of domestic emission sources to air pollution at the background site. Therefore, in the present study, long-term observation of several air pollutants was carried out to obtain a comprehensive understanding of the air pollution at a typical background location. To our knowledge, this is the first exhaustive study involving a detailed air pollutant profile at a background site in Japan.

\section{Materials and Methods}

\subsection{Sampling Site}

Long-term observation for common air pollutants and meteorological parameters was conducted at KUWAMS (Figure 1, Nishifutamata-machi, Wajima City, Ishikawa Prefecture, Japan, $37.4^{\circ} \mathrm{N}, 136.9^{\circ} \mathrm{E}$; $60 \mathrm{~m}$ above sea level). Wajima is situated in the northern Ishikawa Prefecture, Japan, with a population of 26,582 as of 2019/11. Tourism, lacquerware, and fishery are the main local industries [29]. 


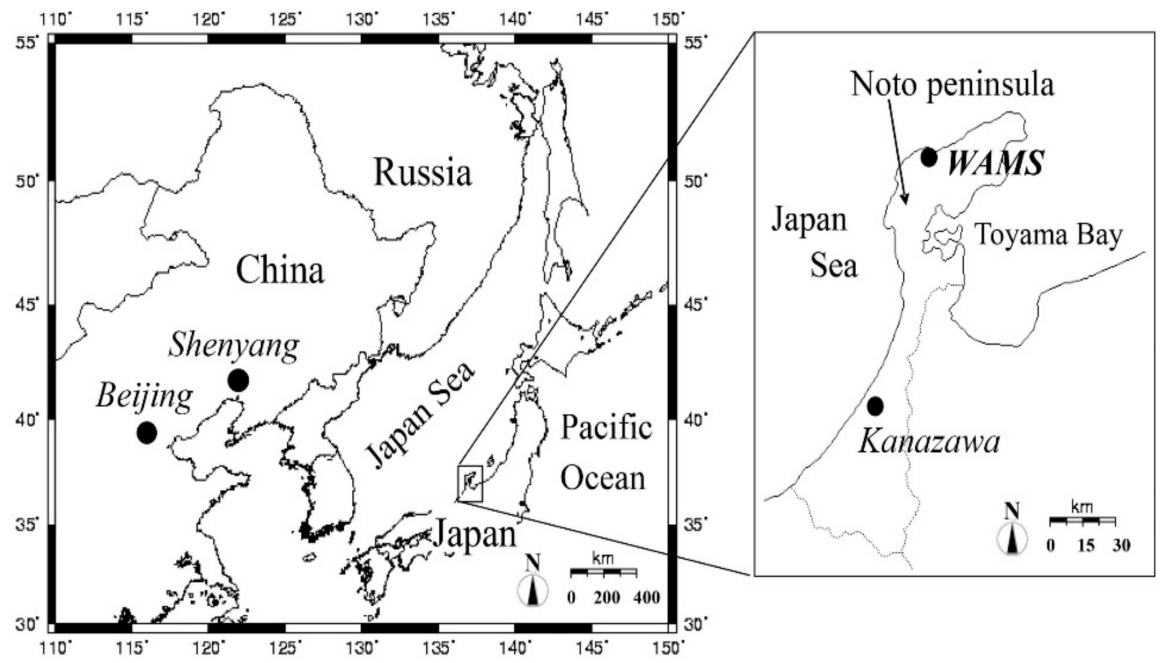

Figure 1. Location of the sampling site. (Kanazawa University Wajima Air Monitoring Station (KUWAMS): $37.4^{\circ} \mathrm{N}, 136.9^{\circ} \mathrm{E} ; 60 \mathrm{~m}$ above sea level [27]).

KUWAMS is encompassed by mountains with an extensive forest and is $2.1 \mathrm{~km}$ south of the Sea of Japan coast. No major industrial emissions occur around this site. Air masses from the Asian continent can pass through KUWAMS in the cold season and domestic Japan in the warm season. Benefitting from its unique location, KUWAMS is a distinctive background air monitoring station for transboundary atmospheric pollutant studies in Japan. In our previous research $[19,21,27,28]$, PAHs collected at KUWAMS were long-range-transported from northeastern China in winter and domestic Japan in summer.

\subsection{Total Suspended Particulate (TSP) Total Sampling and PAH Measurement}

TSPs were collected by a high-volume air sampler (AH-600, Sibata Sci. Tech. Ltd., Saitama, Japan) with a quartz fiber filter ( 8 inch $\times 10$ inch, 2500QAT- UP, Pallflex Products, Putnam, CT, USA) from $2014 / 6$ to 2019/8. The flow rate was $700 \mathrm{~L} \mathrm{~min}^{-1}$. Filters were changed every seven days. After drying in a desiccator in the dark, the filters were weighed and then stored at $-20{ }^{\circ} \mathrm{C}$ until PAH analysis.

A total of nine PAHs (4 to 6 rings) were detected in TSP: fluoranthene (Flu), pyrene (Pyr), benz $[a]$ anthracene $(\mathrm{BaA})$, chrysene $(\mathrm{Chr})$, benzo[b]fluoranthene $(\mathrm{BbF})$, benzo[k]fluoranthene $(\mathrm{BkF})$, benzo[ $[a]$ pyrene, benzo[ghi]perylene (BgPe), and indeno [1,2,3-cd]pyrene (IDP). After pretreatment, high-performance liquid chromatography with fluorescence detection was used to measure the PAH concentrations. Detailed procedures can be found in our previous study [21]. A mixture of PAHs (Untied State Environmental Protection Agency (USEPA) 610 PAH mix) was purchased from Supelco Park (Bellefonte, PA, USA). Two internal standards for PAHs (pyrene- $d 10$ (Pyr- $d 10)$ and benzo[ $a]$ pyrene- $d 12$ (BaP-d12)) were purchased from Wako Pure Chemicals (Osaka, Japan). All other chemicals used were of analytical reagent grade.

\subsection{Online Monitoring of Air Pollutants}

Air pollutants including $\mathrm{PM}_{1}, \mathrm{PM}_{2.5}, \mathrm{NO}_{\mathrm{x}}, \mathrm{SO}_{2}, \mathrm{O}_{3}$, and total hydrocarbons (THC: $\mathrm{CH}_{4}$ and $\mathrm{NMHC}$ ) and the organic carbon (OC) and elemental carbon (EC) in $\mathrm{PM}_{2.5}$ were monitored online from 2014/4 to 2019/8 at KUWAMS. In detail, $\mathrm{PM}_{1}$ and $\mathrm{PM}_{2.5}$ were measured by particulate matter monitor PM-714 in accordance with the Beta eta ray attenuation method with a flow rate of $16.7 \mathrm{~L} / \mathrm{min}$. $\mathrm{NO}_{\mathrm{X}}, \mathrm{SO}_{2}$, and $\mathrm{O}_{3}$ were analyzed at a flow rate of $1 \mathrm{~L} / \mathrm{min}$ with nitrogen oxides analyzer NA-721 (chemiluminescence method), sulfur dioxide analyzer SA-731 (ultraviolet fluorescence method), and ozone analyzer OA-781 (nondispersive ultraviolet absorption method), respectively. THC were monitored with hydrocarbon analyzer HA-771 according to the hydrogen flame ionization detection method at a flow rate of $0.5 \mathrm{~L} / \mathrm{min}$. In addition, the OC and $\mathrm{EC}$ in $\mathrm{PM}_{2.5}$ were measured using 
automatic particulate carbon monitor APC-710 based on the near-infrared/UV absorption method at a flow rate of $16.7 \mathrm{~L} / \mathrm{min}$. Meteorological conditions were simultaneously monitored by the weather Transmitter WXT530 and included temperature $(\mathrm{T})$, relative humidity $(\mathrm{RH})$, pressure $(\mathrm{P})$, wind speed (WS), wind direction (WD), rainfall (rain), and hail. Data per minute, hour, and day were recorded automatically and downloaded from the samplers every month. The detection limit for $\mathrm{NO}_{X}, \mathrm{SO}_{2}$, and $\mathrm{O}_{3}$ was $1 \mathrm{ppb}$. All auto-monitoring instruments were purchased from Kimoto Electric Co. Ltd (Osaka, Japan). In addition, sunshine duration data were downloaded from the Japan Meteorological Agency as supplementary information [30].

\subsection{Quality Control}

Blank filters were processed at the sampling site together with the samples. Three field blank filters were selected randomly from filters with the same lot number. No contamination from filter transport was detected. Before detecting PAHs, standard solutions of each PAH were injected into systems for method validation. The correlation coefficients for the calibration curves of all PAHs were greater than 0.997 . The average recovery of internal standards and each PAH was $100 \% \pm 20 \%$. The detection limit of each PAH was in the range of $0.3-1.3 \mathrm{ng} / \mathrm{mL}$.

The continuous monitoring instruments were checked monthly and exhaustively examined by professionals every year. Outliers resulting from regular maintenance activities (e.g., periodic zero-span checks, calibrations, etc.) and abnormal disruptions were excluded from analysis.

\subsection{Back-Trajectory Analysis}

Backward-trajectory analyses were performed using the window-based HYSPLIT 4 (Hybrid Single-Particle Lagrangian Integrated Trajectory) model developed by the American National Oceanic and Atmospheric Administration (NOAA). HYSPLIT was widely applied on air mass tracking $[22,28,31,32]$. In this study, HYSPLIT was performed to clarify the potential sources of common air pollutants at KUWAMS. Initial height was set as $1000 \mathrm{~m}$. Total run time was set with accordance to atmospheric lifetime of air pollutants.

\subsection{Statistical Analysis}

Hourly data were used to describe the profiles of auto-monitored pollutants and meteorological conditions. Air pollutant concentrations were calculated based on the Manual for Continuous Monitoring of Air Pollution of Japan [33]. The sampling period was divided into warm (June to October) and cold (November to May of the next year) period for PAH analysis due to different sources [21], while four seasons (spring: March to May; summer: June to August; autumn: September to November; winter: December to February of the next year) were used for analysis of the other pollutants based on the distinct seasonal meteorological parameters. Weekly averages were computed for the meteorological parameters and used to perform Spearman correlation analysis to determine their association with PAHs. An independent-samples test was used to compare the differences between annual and seasonal PAH concentrations. A $p$-value of less than 0.05 indicates that the results are statistically significant. Data were evaluated with SPSS 25.0 (IBM Corp., Armonk, New York, USA).

\section{Results and Discussion}

\subsection{Overview}

\subsubsection{PAHs}

Figure 2 and Table 1 present the concentration profile of total PAHs in TSP at KUWAMS from $2014 / 6$ to 2019/8. The concentration of total PAHs ranged from 11 to $1923 \mathrm{pg} / \mathrm{m}^{3}$ with a mean value of $364 \mathrm{pg} / \mathrm{m}^{3}$ during the sampling period. The average concentrations were 143 and $548 \mathrm{pg} / \mathrm{m}^{3}$ in the warm and cold seasons, respectively. Individual PAH concentration widely ranged from 0 to $566 \mathrm{pg} / \mathrm{m}^{3}$ 
with an ascending order of Flu $>\mathrm{Pyr}>\mathrm{BbF}>\mathrm{Chr}>\mathrm{IDP}>\mathrm{BgPe}>\mathrm{BaP}>\mathrm{BkF}>\mathrm{BaA}$. Compared with past data on these nine PAHs at KUWAMS, the concentration of total PAHs in the TSP observed in this study was lower than that observed from 2004 to $2014\left(670 \mathrm{pg} / \mathrm{m}^{3}\right.$ in the cold period and $170 \mathrm{pg} / \mathrm{m}^{3}$ in the warm period).

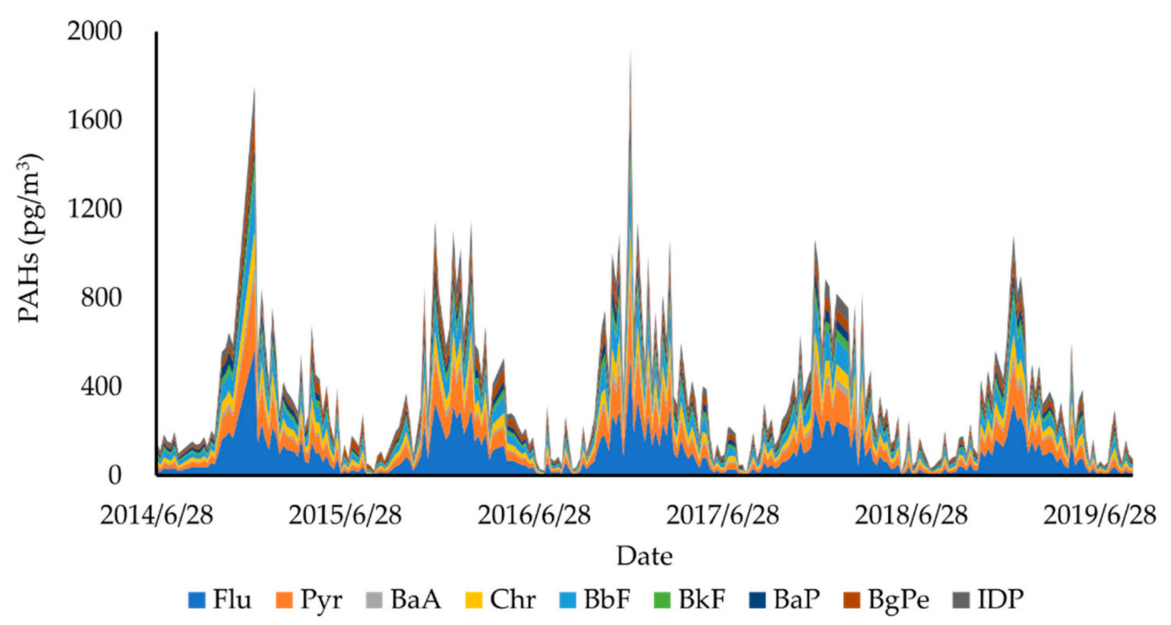

Figure 2. Weekly variation in Polycyclic Aromatic Hydrocarbons (PAHs) from 2014/6 to 2019/8 at Kanazawa University Wajima air monitoring station (KUWAMS).

Table 1. Concentration profiles of PAHs (pg/m $\mathrm{m}^{3}$ ) and TSP $\left(\mu \mathrm{g} / \mathrm{m}^{3}\right)$ from $2014 / 6$ to 2019/8 at Kanazawa University Wajima air monitoring station (KUWAMS).

\begin{tabular}{|c|c|c|c|c|c|c|}
\hline & \multicolumn{2}{|c|}{$\begin{array}{l}\text { Whole Period } \\
\quad(n=2322)\end{array}$} & \multicolumn{2}{|c|}{$\begin{array}{l}\text { Warm Period } \\
(\mathrm{n}=1053)\end{array}$} & \multicolumn{2}{|c|}{$\begin{array}{l}\text { Cold Period } \\
(n=1269)\end{array}$} \\
\hline & Range & Mean \pm SD & Range & Mean \pm SD & Range & Mean \pm SD \\
\hline Flu & $2-566$ & $96 \pm 93$ & $2-123$ & $29 \pm 22$ & $22-566$ & $152 \pm 92$ \\
\hline Pyr & $2-345$ & $61 \pm 56$ & $2-76$ & $21 \pm 14$ & $12-345$ & $94 \pm 57$ \\
\hline $\mathrm{BaA}$ & $0-82$ & $14 \pm 13$ & 0-18 & $5 \pm 3$ & 3-82 & $21 \pm 13$ \\
\hline Chr & $0-167$ & $33 \pm 26$ & $0-49$ & $14 \pm 10$ & $8-167$ & $49 \pm 25$ \\
\hline $\mathrm{BbF}$ & $1-284$ & $54 \pm 43$ & $1-75$ & $23 \pm 15$ & 13-284 & $80 \pm 43$ \\
\hline $\mathrm{BkF}$ & 0-102 & $20 \pm 16$ & $0-28$ & $9 \pm 6$ & 5-102 & $29 \pm 15$ \\
\hline $\mathrm{BaP}$ & $0-129$ & $26 \pm 20$ & $0-37$ & $12 \pm 8$ & $7-129$ & $37 \pm 19$ \\
\hline $\mathrm{BgPe}$ & $1-161$ & $30 \pm 22$ & $1-53$ & $16 \pm 10$ & 10-161 & $41 \pm 23$ \\
\hline IDP & $1-152$ & $31 \pm 24$ & $1-45$ & $14 \pm 9$ & 8-152 & $45 \pm 24$ \\
\hline 4-ring & 7-1130 & $204 \pm 186$ & $7-258$ & $69 \pm 47$ & $47-1130$ & $316 \pm 185$ \\
\hline 5-ring & $2-514$ & $100 \pm 78$ & $2-135$ & $44 \pm 28$ & $25-514$ & $145 \pm 76$ \\
\hline 6-ring & $2-279$ & $61 \pm 45$ & $2-75$ & $31 \pm 17$ & 20-279 & $87 \pm 45$ \\
\hline Total PAHs & $11-1923$ & $364 \pm 307$ & $11-458$ & $143 \pm 90$ & 94-1923 & $548 \pm 302$ \\
\hline TSP & 4-64 & $18 \pm 9$ & $4-242$ & $18 \pm 23$ & 4-64 & $20 \pm 11$ \\
\hline
\end{tabular}

SD: standard variation; Flu: fluoranthene; Pyr: pyrene; BaA: benz[a]anthracene; Chr: chrysene; BbF: benzo[b]fluoranthene; BkF: benzo[k]fluoranthene; BgPe: benzo[ghi]perylene; $\mathrm{BaP}$ : benzo[a]pyrene; IDP: indeno[1,2,3-cd]pyrene; PAHs: Polycyclic Aromatic Hydrocarbons; TSP: Total Suspended Particulate.

In a general comparison with other background sites, the total PAH concentration at KUWAMS was within the ranges detected at urban background sites in Thessaloniki, Greece [34] (5.8 \pm 8.4 and $5.9 \pm 8.5 \mathrm{ng} / \mathrm{m}^{3}$ for $\Sigma 13$ PAHs bound to $\mathrm{PM}_{10}$ and $\mathrm{PM}_{2.5}$, respectively); Dongying, China [35] (18.95 \pm $16.51 \mathrm{ng} / \mathrm{m}^{3}$ for $\Sigma 15$ PAHs bound to $\left.\mathrm{PM}_{18}\right)$; Gosan, Korea [36] (2.9 $\mathrm{ng} \mathrm{m}^{-3}$ for $\sum 14$ PAHs bound to $\mathrm{PM}_{2.5}$, detected in a study on gaseous and particulate PAHs at the Gosan background site in East Asia); and Virolahti, Finland [37] $\left(4.07 \mathrm{ng} / \mathrm{m}^{3}\right.$ for $\sum 11$ PAHs bound to $\left.\mathrm{PM}_{10}\right)$. 


\subsubsection{Continuously Monitored Pollutants and Meteorological Conditions}

Table S1 presents the meteorological parameters at KUWAMS. Spring was characterized by low temperature, relative humidity and pressure, as well as strong solar radiation. Summer was similar to spring but with the highest temperature and lowest pressure. Autumn had the same high relative humidity as summer. Wind speed and air pressure were highest in winter. Generally, all the weather conditions except for air pressure presented the same daily diurnal changes in all seasons. Spring was characterized by the most evident diurnal weather changes. Summer was only slightly weaker than spring but with a less dramatic daytime decrease in relative humidity. Therefore, atmospheric activity (such as oxidation and photolysis) was most active in spring because of the favorable meteorological conditions, followed by summer, and was rather stable in autumn and winter.

Figure 3 and Table S1 represent the concentration profiles of the continuously monitored air pollutants. The daily average concentrations of $\mathrm{PM}_{1}$ and $\mathrm{PM}_{2.5}$ (Figure $3 \mathrm{a}, \mathrm{b}$ ) were $7.1 \pm 5.2$ and $15.9 \pm 9.5 \mu \mathrm{g} / \mathrm{m}^{3}$, respectively. The annual concentrations were $6.7,6.0$, and $7.4 \mu \mathrm{g} / \mathrm{m}^{3}$ for $\mathrm{PM}_{1}$ and 15.4, 14.5, and $16.0 \mu \mathrm{g} / \mathrm{m}^{3}$ for $\mathrm{PM}_{2.5}$ in 2016, 2017, and 2018, respectively. Notably, the $\mathrm{PM}_{2.5}$ concentration at KUWAMS was higher than the annual average concentration in Japan [38] (11.9 and $11.6 \mu \mathrm{g} / \mathrm{m}^{3}$ in 2016 and 2017, respectively; data from the general air monitoring station, same data source below), even exceeding the annual standard for Japan $\left(15 \mu \mathrm{g} / \mathrm{m}^{3}\right)$. Furthermore, a daily mean $\mathrm{PM}_{2.5}$ concentration exceeding the Japan standard $\left(35 \mu \mathrm{g} / \mathrm{m}^{3}\right)$ occurred on 17 days, most of which were in spring ( 6 days in April, 8 days in May, and 1 day each in February, March, and July). The concentrations of OC and EC in $\mathrm{PM}_{2.5}$ (Figure 3c,d) were $0.987 \pm 1.341$ and $0.146 \pm 0.165 \mu \mathrm{g} / \mathrm{m}^{3}$, respectively, which were obviously lower than those detected in $\mathrm{PM}_{2.5}$ at a rural site in China [39] (3.53 and $1.05 \mu \mathrm{g} / \mathrm{m}^{3}$ ). The annual concentrations were $0.504,0.506$, and $1.128 \mu \mathrm{g} / \mathrm{m}^{3}$ for OC and 0.081 , 0.069 , and $0.170 \mu \mathrm{g} / \mathrm{m}^{3}$ for EC in 2016, 2017, and 2018, respectively.

The average concentrations of $\mathrm{SO}_{2}, \mathrm{NO}_{2}$, and $\mathrm{NO}$ (Figure 3e-g) were 0.0-9.9, 0.1-6.7, and 0.0-6.8 ppb, with average values of $0.2 \pm 0.3,0.9 \pm 0.5$, and $0.1 \pm 0.3 \mathrm{ppb}$, respectively. Data per minute of $98 \%, 65 \%, 97 \%$ were lower than the detection limit for $\mathrm{SO}_{2}, \mathrm{NO}_{2}$, and $\mathrm{NO}$, respectively. During the sampling period, the atmospheric levels of $\mathrm{SO}_{2}, \mathrm{NO}_{2}$, and $\mathrm{NO}$ were almost ten times lower than the average levels in Japan in 2016 and 2017 (9 ppb NO 2,2 (2017)-3 (2016) ppb NO, 2 ppb SO 2 ). The daily $1 \mathrm{~h}$ max average $\mathrm{O}_{3}$ concentration (Figure $3 \mathrm{~h}$ ) was $43.6 \pm 16.2$ (15.3-105.9) ppb, and the daily $16 \mathrm{~h}$ average $\mathrm{O}_{3}$ concentration (from 5:00 to 20:00) was $31.5 \mathrm{ppb}$. Notably, there were $12 \%$ days with a $1 \mathrm{~h}$ daytime value higher than the Japanese standard (60 ppb), indicating a significant atmospheric concentration of $\mathrm{O}_{3}$ at KUWAMS. In addition, the annual concentration was $39.2 \pm 12.9,44.8 \pm 14.0$, and $43.6 \pm 14.8 \mu \mathrm{g} / \mathrm{m}^{3}$ for the daily $1 \mathrm{~h}$ max average and $28.5 \pm 14.8,31.7 \pm 17.0$, and $30.5 \pm 16.6 \mu \mathrm{g} / \mathrm{m}^{3}$ for the $16 \mathrm{~h}$ average in 2016, 2017, and 2018, which were lower than the average level in Japan in 2016 and 2017. NMHC and $\mathrm{CH}_{4}$ (Figure $3 \mathrm{i}, \mathrm{j}$ ) showed stable concentrations during the sampling period, with average concentrations of $0.04 \pm 0.04$ and $1.88 \pm 0.04 \mathrm{ppmC}$, respectively. As a precursor of $\mathrm{O}_{3}$, the $3 \mathrm{~h}$ (from 6 to 9 a.m.) average NMHC standard is set to $0.2-0.31 \mathrm{ppmC}$ as a reference value for the prediction of the daytime $\mathrm{O}_{3}$ concentration in Japan. The $3 \mathrm{~h}$ mean concentration of NMHC was $0.04 \pm 0.04 \mathrm{ppmC}$ at KUWAMS, which was lower than the average value in Japan in 2016 and 2017 (0.12 ppmC in both years) and the Japanese standard.

The atmospheric concentrations of common air pollutants at KUWAMS, as a remote site, were basically at background levels. However, $\mathrm{PM}_{2.5}$ and $\mathrm{O}_{3}$ (listed in six pollutant criteria in Japan) were detected at high concentrations during the observation period, which highlights the importance of clarifying their sources, variations, and impacting factors. 

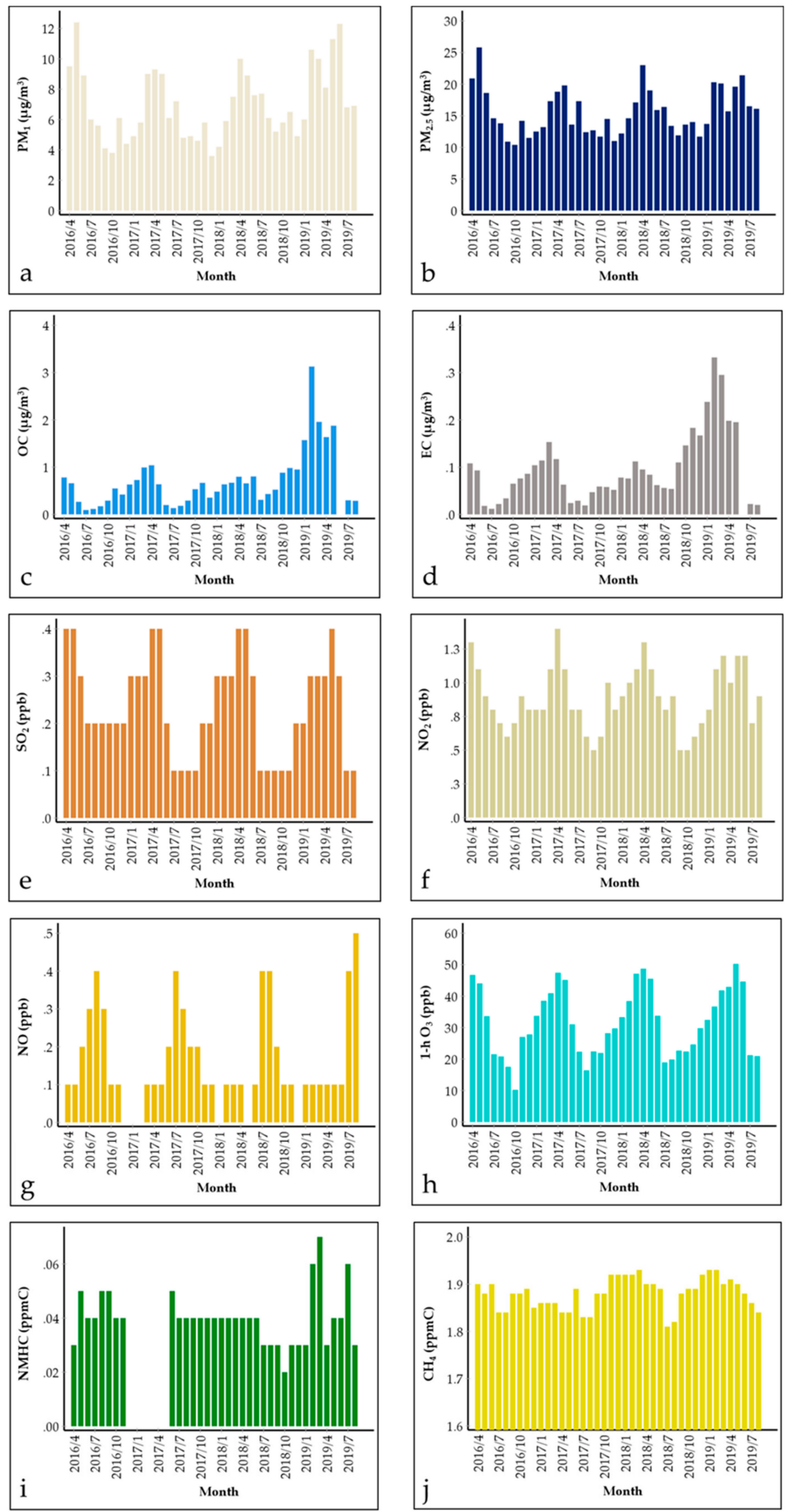

Figure 3. Monthly variation in continuously monitored pollutants from 2014/6 to 2019/8 at Kanazawa University Wajima air monitoring station (KUWAMS). (a) $\mathrm{PM}_{1}\left(\mu \mathrm{g} / \mathrm{m}^{3}\right)$; (b) $\mathrm{PM}_{2.5}\left(\mu \mathrm{g} / \mathrm{m}^{3}\right)$; (c) OC $\left(\mu \mathrm{g} / \mathrm{m}^{3}\right)$; (d) EC ( $\left.\mu \mathrm{g} / \mathrm{m}^{3}\right)$; (e) $\mathrm{SO}_{2}$ (ppb); (f) $\mathrm{NO}_{2}$ (ppb); (g) $\mathrm{NO}$ (ppb); (h) 1-h O $\mathrm{O}_{3}$ (ppb); (i) NMHC (ppmC); (j) $\mathrm{CH}_{4}(\mathrm{ppmC})$. 


\subsection{Annual, Seasonal and Diurnal Variations}

\subsubsection{Yearly Variations in PAHs}

In general, total PAHs decreased $13 \%$ in the cold season (from $527 \mathrm{pg} / \mathrm{m}^{3}$ in 2014 to $456 \mathrm{pg} / \mathrm{m}^{3}$ in 2018) and $14 \%$ in the warm season (from $154 \mathrm{pg} / \mathrm{m}^{3}$ in 2014 to $132 \mathrm{pg} / \mathrm{m}^{3}$ in 2019). Obvious variation was observed during the 5 years study, with a more pronounced annual divergence in the cold season ( $p=0.060-0.341)$ than in the warm season $(p=0.108-0.997)$. In detail, in the cold period, PAH concentrations showed a single peak pattern: the concentration of total PAHs increased from $527 \mathrm{pg} / \mathrm{m}^{3}$ (2014) to $534 \mathrm{pg} / \mathrm{m}^{3}$ (2015) and peaked at $609 \mathrm{pg} / \mathrm{m}^{3}$ in 2016. Then, the PAH concentration decreased to $509 \mathrm{pg} / \mathrm{m}^{3}$ in 2017 and to $456 \mathrm{pg} / \mathrm{m}^{3}$ in 2018. On the other hand, relatively small wavy fluctuations occurred in the warm period. The average concentrations were 154, 161, 145, 154, 107, and $132 \mathrm{pg} / \mathrm{m}^{3}$ in each year from 2014 to 2019.

Based on our previous studies $[19,21,27,28]$, PAHs were mainly transported from the Asian continent in the cold season and domestic Japan in the warm season. For instance, preparation for Beijing Olympic Games in China caused an evident change during cold season from 2006 to 2009, while reconstruction after Noto peninsula earthquake led to a gradual increase from 2007 to 2010 during warm season [21]. In the recent years, PAH concentration revealed a descending trend in the cold and warm season, which might benefit from the air pollution control measures in both regions [38,40]. In addition, the annual variation in total PAHs was caused by the simultaneous fluctuation of 4- to 6-ring PAHs in the cold season, along with a synchronous change in the total PAH/TSP ratio (not shown here), suggesting the evident impact of Asian Continent flow. However, the simultaneous changes in total PAHs, 4- to 6-ring PAHs, and the total PAH/TSP ratio were not seen in the warm season due to more mixed sources (domestic Japan and local).

\subsubsection{Seasonal and Diurnal Variations in the Continuously Monitored Pollutants}

Figure 3, Figure S1, and Table S2 display the seasonal and diurnal variations in the auto-monitored pollutants. $\mathrm{PM}_{1}$ and $\mathrm{PM}_{2.5}$ (Figure $3 \mathrm{a}, \mathrm{b}$ ) concentrations had the same seasonality: spring > summer > winter, autumn. It is thought that natural sources such as seasonal pollen and sea salt dominantly contribute to the PM variation at KUWAMS due to its surrounding environment. Additionally, Asian dust is prevailing in spring and can be long-range-transported to Japan, contributed to higher PM level in spring at KUWAMS [41,42]. Besides, distinct peaks in autumn (especially November) were displayed in $\mathrm{PM}_{1}$ and $\mathrm{PM}_{2.5}$, suggesting the probable contribution of local agricultural residue burning. Winter is the "clean" season due to lack of primary emission and weak atmospheric reactions. Daily $\mathrm{PM}_{2.5}$ variation (Figure S1b) reached a valley at approximately 9:00 and peaked at 18:00, and decreased steadily at night. $\mathrm{PM}_{1}$ was associated with $\mathrm{PM}_{2.5}$ on the season level but with a more solar radiation dependence in diurnal variation. The ratio of $\mathrm{PM}_{1} / \mathrm{PM}_{2.5}$ was $44 \%$, which was lower than that of the Gosan ABC superstation in Korea [43] (60.8\%, August 2017-September 2018) and Tuoji Island in China [44] (72\%, winter 2014). Nevertheless, $\mathrm{PM}_{1}$ variation (Figure S1a) displayed no valley in the late morning but a moderately broad peak (narrower in autumn and winter) from 8:00 to 20:00. Increasing daytime concentrations indicated secondary aerosol formation of $\mathrm{PM}_{1}$ and $\mathrm{PM}_{2.5}$, while the difference in the daily $\mathrm{PM}_{1}$ and $\mathrm{PM}_{2.5}$ variations was probably caused by the diversity in the components resulting from the different particle diameters [45,46]. Water-soluble inorganic ions (WSII) are a significant component of PM [47], especially in the coastal area. It was observed that secondary WSII displayed size-fractioned characteristics as significantly abundant in $\mathrm{PM}_{1}[43,44]$, which probably led to $\mathrm{PM}_{1}$ increase in the daytime. OC and EC (Figure 3c,d) also peaked in spring (winter $>$ autumn > summer). The daytime variation (Figure S1c,d) was different from that of $\mathrm{PM}_{2.5}$, and similar fluctuations were observed in only OC and $\mathrm{PM}_{1}$. The OC/EC ratio over 2 indicates formation of secondary organic carbon (SOC) [48]. In the current study, the mean value of OC/EC was 6.8 . 
$\mathrm{SO}_{2}, \mathrm{NO}_{2}$, and $\mathrm{O}_{3}$ displayed similar seasonal variations (Figure $3 \mathrm{e}, \mathrm{f}, \mathrm{h}$ ), spring $>$ winter $>$ summer $>$ autumn, and diurnal variations (Figure S1e,f,h), daytime $>$ night, indicating the important impact of external inputs. Spring peak of $\mathrm{O}_{3}$ commonly occurs at Northern hemisphere, which was explained by various mechanisms [49]. It is thought that air pollutants including $\mathrm{O}_{3}$ precursors were long-range transported from continental flow in cold season (winter and spring), and the formation of $\mathrm{O}_{3}$ was strengthened by the mounting solar radiation from winter to spring. Low concentration in summer and autumn can be explained by lack of $\mathrm{O}_{3}$ precursors and strengthened wash-out effect due to frequent precipitation. Daily $\mathrm{O}_{3}$ concentration was dependent on solar radiation intensity. Furthermore, two peaks were detected in the daytime $\mathrm{NO}_{2}$ concentration in summer. $\mathrm{NO}_{2}$ first peaked in value at 8:00, reached a valley at 14:00, and then peaked again at 18:00. It is thought that $\mathrm{NO}_{2}$ photolyzed to produce $\mathrm{O}_{3}$ in the daytime in summer.

The NO concentration (Figure 3g, Figure S1g) was extremely low at KUWAMS because of scarce anthropogenic emissions in the area $[19,21,27,28]$. Interestingly, the NO concentration was highest in summer, resulting from vehicle emission due to increasing tourists. Besides, a morning peak occurred at approximately 8:00 in each season, which was most evident in spring and summer (occurred at 10:00 in winter), suggesting a contribution from passing vehicles, since KUWAMS is located near a shortcut from Anamizuvillage to Wajima City, despite the light traffic.

$\mathrm{CH}_{4}$ (Figure 3i, Figure S1i) presented a seasonal variation of winter $>$ spring $>$ autumn $>$ summer but no evident daily variation. Seasonal features of $\mathrm{CH}_{4}$ in a background environment are correlated with its atmospheric reaction with hydroxyl radical, which depends on the seasonal intensity of ultraviolet radiation [50]. No obvious seasonal trend was displayed in NMHC (Figure 3j). In spring and summer, the concentration of NMHC reached a daily high at 14:00 (Figure S1j). KUWAMS is encompassed with abundant forest, which can produce considerable isoprene. Thus, the daily high was probably due to isoprene variation [51]. Nevertheless, it should be further explored since only total NMHC concentrations were available in this study.

In general, significant atmospheric concentration levels of common air pollutants were primarily observed in spring. Diurnal concentration changes were most evident in spring and summer at KUWAMS.

\subsection{Meteorological Conditions}

Atmospheric levels of PAHs can be influenced by meteorological parameters [21,27]. Spearman correlation was conducted to clarify the correlations of PAH concentrations with meteorological conditions. As shown in Table 2, a negative relationship was found between temperature and all PAHs at KUWAMS, which was stronger in the cold season and for the 4-ring PAHs. The physicochemical properties of PAHs can affect the phase in which they reside. As the temperature increases, 4-ring PAHs with high vapor pressure are more prone to volatilize into the gas phase from the particulate phase than PAHs with more rings [52,53]. In contrast, pressure was positively associated with the concentrations of each PAH, especially those of 4-ring PAHs, which can be explained by the negative relation between pressure and temperature [21]. Additionally, wind speed increased PAH levels in the cold season. Generally, wind can accelerate air flow, which affects the process by which local air pollutants spread to downwind sites or are transported from distant locations. A positive correlation indicated that a surrounding air mass containing PAHs was transported to KUWAMS. Finally, no significant correlations were found between the relative humidity and any of the PAHs. 
Table 2. Spearman correlation among PAHs and meteorological condition 2014/6 to 2019/8 in the (a) cold season $(n=94)$ and $(b)$ warm season $(n=80)$.

\begin{tabular}{|c|c|c|c|c|c|c|}
\hline \multicolumn{7}{|c|}{ (a) } \\
\hline Pollutants & $\mathbf{T}$ & RH & $\mathbf{P}$ & WS & Rain & Sunshine \\
\hline Flu & $-0.707^{* *}$ & 0.190 & $0.517^{* *}$ & $0.377^{* *}$ & 0.260 * & -0.645 \\
\hline Pyr & $-0.684^{* *}$ & 0.179 & $0.501 * *$ & $0.373^{* *}$ & $0.287^{* *}$ & $-0.617^{* *}$ \\
\hline $\mathrm{BaA}$ & $-0.696^{* *}$ & 0.189 & $0.535^{* *}$ & $0.421^{* *}$ & $0.304^{* *}$ & $-0.634^{* *}$ \\
\hline Chr & $-0.539 * *$ & 0.149 & $0.422 * *$ & $0.278^{* *}$ & 0.236 * & $-0.511^{* *}$ \\
\hline $\mathrm{BbF}$ & $-0.590^{* *}$ & 0.189 & $0.473^{* *}$ & $0.304^{* *}$ & $0.271^{* *}$ & $-0.582^{* *}$ \\
\hline $\mathrm{BkF}$ & $-0.563^{* *}$ & 0.161 & $0.468^{* *}$ & $0.321^{* *}$ & $0.269 * *$ & $-0.552^{* *}$ \\
\hline $\mathrm{BaP}$ & $-0.481^{* *}$ & 0.109 & $0.427^{* *}$ & $0.333^{* *}$ & $0.292^{* *}$ & $-0.485^{* *}$ \\
\hline $\mathrm{BgPe}$ & $-0.434^{* *}$ & 0.121 & $0.399 * *$ & $0.208^{*}$ & 0.219 * & $-0.446^{* *}$ \\
\hline IDP & $-0.582 * *$ & 0.193 & $0.471^{* *}$ & $0.312^{* *}$ & $0.278^{* *}$ & $-0.577^{* *}$ \\
\hline 4-ring & $-0.686^{* *}$ & 0.181 & 0.502 ** & $0.371^{* *}$ & $0.275^{* *}$ & $-0.628^{* *}$ \\
\hline 5-ring & $-0.559 * *$ & 0.166 & $0.465^{* *}$ & $0.317^{* *}$ & $0.278 * *$ & $-0.557^{* *}$ \\
\hline 6-ring & $-0.523^{* *}$ & 0.169 & $0.443^{* *}$ & 0.260 * & 0.251 * & $-0.524^{* *}$ \\
\hline Total PAHs & $-0.634^{* *}$ & 0.169 & $0.486^{* *}$ & $0.345^{* *}$ & $0.276^{* *}$ & $-0.597^{* *}$ \\
\hline \multicolumn{7}{|c|}{ (b) } \\
\hline Pollutants & $\mathrm{T}$ & RH & $\mathbf{P}$ & WS & Rain & Sunshine \\
\hline Flu & $-0.521^{* *}$ & -0.147 & $0.476^{* *}$ & 0.206 & 0.004 & -0.080 \\
\hline Pyr & $-0.442^{* *}$ & -0.121 & $0.445^{* *}$ & 0.128 & -0.052 & -0.067 \\
\hline $\mathrm{BaA}$ & $-0.362^{* *}$ & -0.089 & $0.392 * *$ & 0.124 & -0.062 & -0.006 \\
\hline Chr & $-0.310^{* *}$ & -0.083 & $0.331^{* *}$ & 0.104 & -0.070 & 0.024 \\
\hline $\mathrm{BbF}$ & $-0.306^{* *}$ & -0.053 & $0.341^{* *}$ & 0.118 & -0.037 & -0.011 \\
\hline $\mathrm{BkF}$ & $-0.313^{* *}$ & -0.069 & $0.346^{* *}$ & 0.115 & -0.048 & -0.007 \\
\hline $\mathrm{BaP}$ & $-0.267^{*}$ & -0.120 & $0.301 * *$ & 0.109 & -0.106 & 0.093 \\
\hline $\mathrm{BgPe}$ & $-0.261 *$ & -0.107 & $0.298^{* *}$ & 0.127 & -0.053 & 0.033 \\
\hline IDP & $-0.338^{* *}$ & -0.049 & $0.335^{* *}$ & 0.078 & -0.085 & -0.005 \\
\hline 4-ring & $-0.460^{* *}$ & -0.118 & $0.450 * *$ & 0.166 & -0.019 & -0.064 \\
\hline 5-ring & $-0.304^{* *}$ & -0.070 & $0.333^{* *}$ & 0.109 & -0.059 & 0.012 \\
\hline 6-ring & $-0.310^{* *}$ & -0.075 & $0.323^{* *}$ & 0.106 & -0.054 & 0.005 \\
\hline Total PAHs & $-0.372^{* *}$ & -0.093 & $0.386^{* *}$ & 0.145 & -0.038 & -0.020 \\
\hline
\end{tabular}

\subsection{Source Apportionment}

\subsubsection{Diagnostic Ratios (DRs) of PAHs}

Atmospheric PAHs primarily originate from the incomplete combustion and pyrolysis of organic matter [33], and different sources differ in the dominant PAHs and/or the proportions of specific PAHs $[34,35]$. The type of PAHs produced strongly depends on the combustion temperature $[54,55]$. PAHs with low molecular weight are generated via low-temperature burning, whereas high-molecular-weight PAHs account for a larger proportion with increasing temperature. The DRs of specific PAHs are extensively used to infer PAH sources $[12,19,21,22,28,56]$. Typical DRs are listed in Table 3. Taking the ratio of $\mathrm{Flu} /(\mathrm{Flu}+\mathrm{Pyr})$ as an example, a value below 0.4 indicates unburned petroleum as the main PAH source, a value from 0.4 to 0.5 suggests a liquid fossil fuel source, and a value above 0.5 implies that wood and coal combustion make a large contribution to PAHs. In this study, the mean concentration ratios of Flu/(Flu/Pyr), BaA/(BaA + Chr), IDP/(IDP + BgPe), BbF/(BbF $+\mathrm{BkF})$, and $\mathrm{BaP} / \mathrm{BgPe}$ in the cold (warm) season were 0.53-0.68 (0.24-0.66), 0.19-0.40 (0.16-0.60), $0.20-0.72$ (0.15-0.65), 0.70-0.76 (0.70-0.87), and 0.22-2.31 (0.20-1.84), respectively, suggesting that PAHs were mainly from mixed sources including coal and biomass combustion and vehicle emission. Moreover, $\mathrm{BaA} /(\mathrm{BaA}+\mathrm{Chr})$ was also used to identify fresh and aged air masses. Relatively low 
$\mathrm{BaA} /(\mathrm{BaA}+\mathrm{Chr})$ ratios were found in both the warm and cold periods, suggesting a predominant proportion of PAHs that had undergone reaction or long-range transport, instead of PAHs from local emissions, at KUWAMS, which was consistent with our previous report [21,22,27]. However, factors such as complicated atmospheric behavior can result in spatiotemporal changes in atmospheric PAHs. Thus, DRs should be used with prudence or primarily to study PAH fingerprints.

Table 3. Diagnostic ratios (DRs) of Polycyclic Aromatic Hydrocarbons (PAHs).

\begin{tabular}{|c|c|c|c|c|}
\hline Diagnostic Ratio & Value Range & Source & Cold Season & Warm Season \\
\hline Flu/(Flu + Pyr) & $\begin{array}{l}<0.4 \\
>0.4 \\
0.4-0.5 \\
<0.5 \\
>0.5\end{array}$ & $\begin{array}{l}\text { Unburned petroleum }[57,58] \\
\text { Petrogenic }[57,58] \\
\text { Liquid fossil fuel }[57,58] \\
\text { Gasoline } \\
\text { Wood and coal combustion }[58] \\
\text { Diesel [59] }\end{array}$ & $0.53-0.68(0.61)$ & $0.24-0.66(0.54)$ \\
\hline $\mathrm{BaA} /(\mathrm{BaA}+\mathrm{Chr})$ & $\begin{array}{l}0.2-0.35 \\
>0.35\end{array}$ & $\begin{array}{l}\text { Coal combustion }[58,60] \\
\text { Vehicular emission }[58,60]\end{array}$ & $0.19-0.40(0.29)$ & $0.16-0.60(0.26)$ \\
\hline IDP/(IDP + BgPe) & $\begin{array}{c}0.18 \\
<0.2 \\
0.2-0.5 \\
0.56 \\
0.62 \\
>0.5\end{array}$ & $\begin{array}{l}\text { Cars [61] } \\
\text { Petrogenic }[58,60] \\
\text { Petroleum combustion }[58,60] \\
\text { Coal [61] } \\
\text { Wood burning }[61] \\
\text { Grass, wood and coal } \\
\text { combustion }[58,60]\end{array}$ & $0.20-0.72(0.52)$ & $0.15-0.65(0.46)$ \\
\hline $\mathrm{BbF} /(\mathrm{BbF}+\mathrm{BkF})$ & $0.70-0.76$ & Coal combustion [22] & $0.70-0.76(0.73)$ & $0.70-0.87(0.73)$ \\
\hline $\mathrm{BaP} / \mathrm{BgPe}$ & $\begin{array}{l}0.5-0.6 \\
<1.0 \\
>1.25\end{array}$ & $\begin{array}{l}\text { Traffic emission [61] } \\
\text { Vehicle }[62,63] \\
\text { Brown coal }[61]\end{array}$ & $0.22-2.31(0.86)$ & $0.20-1.84(0.73)$ \\
\hline
\end{tabular}

\subsubsection{Back-Trajectory Analysis}

Based on the above results, spring was the most "polluted" seasons, with high external air pollutant input. Thus, back-trajectory analysis was performed to trace the possible source of air pollutants in spring at KUWAMS from 2016/4 to 2019/5. The starting height was set to $1000 \mathrm{~m}$ above ground level, and the starting time was set at each hour from 11:00 to 15:00 because the concentration peak of most pollutants was found to fall in this time interval. Trajectories of air masses were tracked every day and clustered into appropriate numbers of groups for further analysis. The final result is shown in Figure 4.

As shown in Figure 4, the air masses transported to KUWAMS were mainly from the Asian continent and domestic Japan in nearly comparable contributions. In detail, 56\% of the air masses derived from the Asian continent (northern China) passed over North Korea and the Pacific Ocean and arrived at KUWAMS. The other source was the Kansai Region (Osaka et al.) of Japan, from which air masses passed over the Sea of Japan before finally reaching the sampling site. China is a dominant source of Asian air pollution due to its fast-developing economy. Adjacent locations and favorable meteorological conditions enable the long-range transport of pollutants via air masses. However, high $\mathrm{O}_{3}$ concentrations also occur in Japanese metropolitan areas, such as Osaka [38], due to considerable vehicle emissions, especially in spring. Nevertheless, the atmospheric lifetimes of $\mathrm{SO}_{2}, \mathrm{NO}_{2}$, and $\mathrm{O}_{3}$ are on order of days, and these species can actively take part in atmospheric reactions. It is unlikely that these short-lived pollutants have direct impacts on remote sites. However, it is thought that short-lived pollutants can be transported to distant locations in different forms. For example, peroxyacetyl nitrates (PAN) are important photooxidants and are generated from only anthropogenic sources by the reaction of $\mathrm{NO}_{x}$ and acetaldehyde. PAN can be removed via thermal decomposition reactions and yield $\mathrm{NO}_{2}$. Due to its temperature sensitivity, PAN can be transported to remote sites at low temperature and release $\mathrm{NO}_{2}$ upon decomposition at increased temperature at the remote site [26]. Sadanaga et al. [36] concluded that total PAN and total organic nitrates undergo long-range transport from the Asian 
continent to the Noto Peninsula. Thus, it is speculated that these were possibly originated from aged air masses by long-range transport from northern China and from freshly polluted plumes from domestic Japan. Nevertheless, this speculation needs to be further confirmed due to lack of other pollutant data such as that of PAN. In addition, natural sources, such as dimethyl sulfide oxidation to produce $\mathrm{SO}_{2}$ and microbial decomposition to generate $\mathrm{SO}_{2}$ and $\mathrm{NO}_{\mathrm{x}}$, also have an impact on pollutant concentrations at KUWAMS.

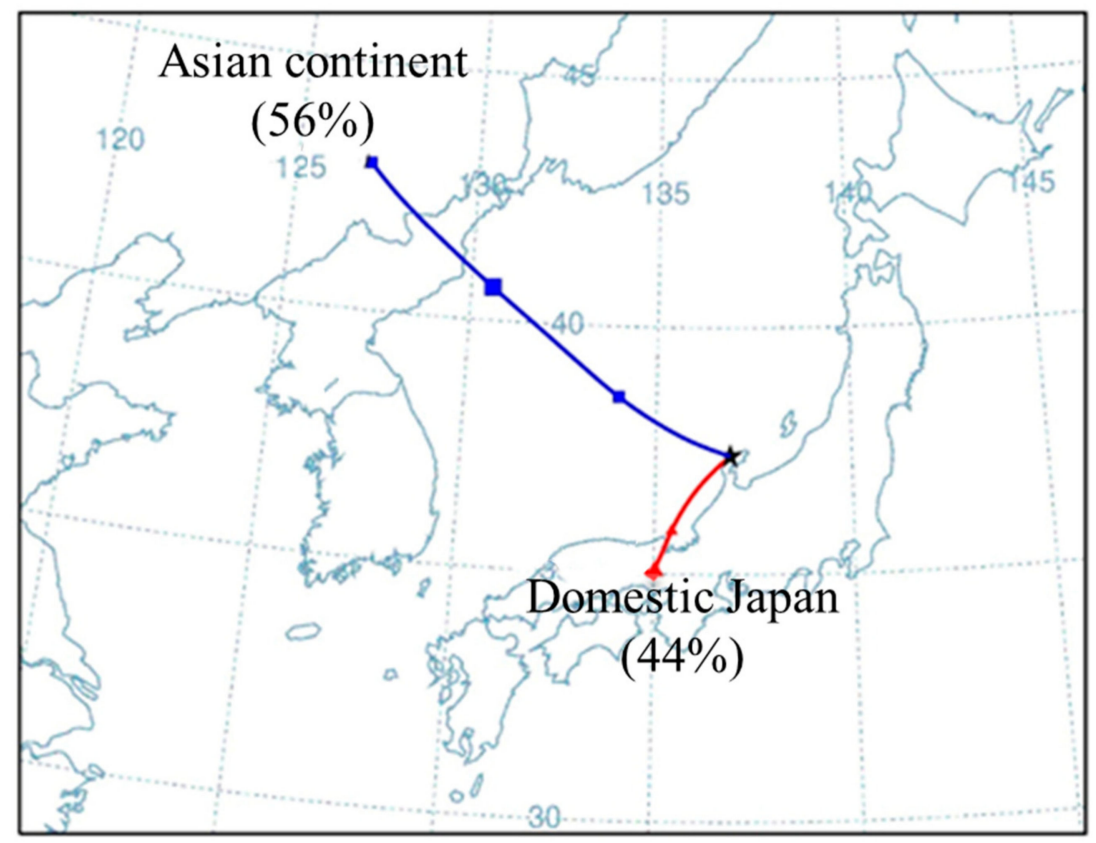

Figure 4. Back-trajectory analysis in spring from 2016/4 to 2019/5 at Kanazawa University Wajima air monitoring station (KUWAMS) $\left(37.4^{\circ} \mathrm{N}, 136.9^{\circ} \mathrm{E}\right)$. Starting time: every hour from 11:00 to 15:00; Starting height: $1000 \mathrm{~m}$ above ground level.

\section{Conclusions}

In this study, long-term observation of TSP-bound PAHs (5 years) and multiple gaseous pollutants (4 years) was performed at a typical remote background site. Based on the results, the yearly concentration of PAHs decreased from 2014 to 2019 in the cold and warm period, indicating a reduction trend in China and Japan, which resulted from effective implementation of pollution control measures. Diagnostic ratios suggested that PAHs collected at KUWAMS were generated by mixed sources containing coal and biomass burning, as well as vehicle emission. Meteorological conditions played important parts in PAHs atmospheric activity. On the other hand, common air pollutants were present at relatively low levels but with pronounced seasonal features, and high concentrations of $\mathrm{PM}_{2.5}$ and $\mathrm{O}_{3}$ that exceeded the Japanese standards were detected. $\mathrm{CH}_{4}$ and $\mathrm{NMHC}$ displayed steady concentration level during sampling period with a winter high occurred in $\mathrm{CH}_{4}$. Gaseous pollutants probably derived from northern China and domestic Japan in spring, while local sources such as pollen, sea salt, vehicle emission, and biomass burning also contributed to atmospheric pollution at KUWAMS.

Supplementary Materials: The following are available online at http://www.mdpi.com/1660-4601/17/3/957/s1, Table S1: Concentration profiles of continuously monitored pollutants and meteorological conditions from 2016/4 to 2019/8 at Kanazawa University Wajima air monitoring station (KUWAMS), Table S2: Seasonal concentration profiles (mean \pm SD) of continuously monitored pollutants and meteorological conditions from 2016/4 to 2019/8 at Kanazawa University Wajima air monitoring station (KUWAMS); Figure S1: Diurnal variation of continuously monitored pollutants from 2016/4 to 2019/8 at Kanazawa University Wajima air monitoring station (KUWAMS). (blue line: spring, red line: summer, green line: autumn, orange line: winter).

Author Contributions: N.T. designed the sampling work, PAHs analyses for particulate matters; N.T., L.Z., L.Y., Q.Z., X.Z. and W.X. collected samples and conducted monitoring work; X.Z. analyzed the PAHs; X.Z. and Q.Z. 
performed statistical analysis; N.T. and L.Z. gave recommend to the paper. K.H., A.T. and Y.W. gave the review and comment during the creating process of the paper. X.Z. and N.T. wrote the paper. All authors have read and agreed to the published version of the manuscript.

Acknowledgments: This work was supported by the Ministry of Education, Culture, Sports, Science and Technology, Japan (17K08388, 24406020); the Environment Research and Technology Development Fund (5-1951) of the Environmental Restoration and Conservation Agency of Japan; the Sumitomo Foundation, Japan (183115); the Bilateral Open Partnership Joint Research Projects of the Japan Society for the Promotion of Science, Japan; the CHOZEN Project of Kanazawa University, Japan; and the Institute of Nature and Environmental Technology, Kanazawa University, Japan (19005, 19006, 19007, 19008). We thank the National Oceanic and Atmospheric Administration Air Resources Laboratory for providing the HYSPLIT 4 model (window-based). The authors acknowledge the Institute of Nature and Environmental Technology, Kanazawa University for the provision of the scientific data used in this publication (https://ki-net.db.kanazawa-u.ac.jp/).

Conflicts of Interest: The authors declare no conflict of interest.

\section{References}

1. Jerrett, M. The death toll from air-pollution sources. Nature 2015, 525, 330-331. [CrossRef] [PubMed]

2. Künzli, N.; Kaiser, R.; Medina, S.; Studnicka, M.; Chanel, O.; Filliger, P.; Herry, M.; Horak, F.; Puybonnieux-Texier, V.; Quénel, P.; et al. Public-health impact of outdoor and traffic-related air pollution: A European assessment. Lancet Lond. Engl. 2000, 356, 795-801. [CrossRef]

3. Kan, H.D.; Chen, R.J.; Tong, S.L. Ambient air pollution, climate change, and population health in China. Environ. Int. 2012, 42, 10-19. [CrossRef] [PubMed]

4. O'Brien, R.L.; Neman, T.; Rudolph, K.; Casey, J.; Venkataramani, A. Prenatal exposure to air pollution and intergenerational economic mobility: Evidence from U.S. county birth cohorts. Soc. Sci. Med. 2018, 217, 92-96. [CrossRef]

5. Law, K.S.; Stohl, A. Arctic Air Pollution: Origins and Impacts. Science 2007, 315, 1537-1540. [CrossRef]

6. World Health Organization. Air Pollution. Available online: https://www.who.int/health-topics/airpollution\#tab=tab_1 (accessed on 19 December 2019).

7. Zhang, L.L.; Morisaki, H.; Wei, Y.J.; Li, Z.; Yang, L.; Zhou, Q.Y.; Zhang, X.; Xing, W.L.; Hu, M.; Shima, M.; et al. Characteristics of air pollutants inside and outside a primary school classroom in Beijing and respiratory health impact on children. Environ. Pollut. 2019, 255, 113147. [CrossRef]

8. Phosri, A.; Ueda, K.; Phung, V.L.H.; Tawatsupa, B.; Honda, A.; Takano, H. Effects of ambient air pollution on daily hospital admissions for respiratory and cardiovascular diseases in Bangkok, Thailand. Sci. Total Environ. 2019, 651, 1144-1153. [CrossRef]

9. Deng, Q.H.; Lu, C.; Li, Y.G.; Chen, L.; He, Y.R.; Sundell, J.; Norbäck, D. Association between prenatal exposure to industrial air pollution and onset of early childhood ear infection in China. Atmos. Environ. 2017, 157, 18-26. [CrossRef]

10. Koren, H.S. Associations between criteria air pollutants and asthma. Environ. Health Perspect. 1995, 103, 8.

11. Boström, C.-E.; Gerde, P.; Hanberg, A.; Jernström, B.; Johansson, C.; Kyrklund, T.; Rannug, A.; Törnqvist, M.; Victorin, K.; Westerholm, R. Cancer Risk Assessment, Indicators, and Guidelines for Polycyclic Aromatic Hydrocarbons in the Ambient Air. Environ. Health Perspect. 2002, 110, 451-489.

12. Zhang, L.L.; Morisaki, H.; Wei, Y.J.; Li, Z.G.; Yang, L.; Zhou, Q.Y.; Zhang, X.; Xing, W.L.; Hu, M.; Shima, M.; et al. $\mathrm{PM}_{2.5}$-bound polycyclic aromatic hydrocarbons and nitro-polycyclic aromatic hydrocarbons inside and outside a primary school classroom in Beijing: Concentration, composition, and inhalation cancer risk. Sci. Total Environ. 2020, 705, 135840. [CrossRef] [PubMed]

13. Zhang, L.L.; Tokuda, T.; Yang, L.; Zhou, Q.; Zhang, X.Y.; Xing, W.L.; Wu, Q.; Zhou, Z.J.; Chen, R.; Kameda, T.; et al. Characteristics and Health Risks of Particulate Polycyclic Aromatic Hydrocarbons and Nitro-polycyclic Aromatic Hydrocarbons at Urban and Suburban Elementary Schools in Shanghai, China. Asian J. Atmos. Environ. 2019, 13, 266-275. [CrossRef]

14. Chiang, T.-Y.; Yuan, T.-H.; Shie, R.-H.; Chen, C.-F.; Chan, C.-C. Increased incidence of allergic rhinitis, bronchitis and asthma, in children living near a petrochemical complex with $\mathrm{SO}_{2}$ pollution. Environ. Int. 2016, 96, 1-7. [CrossRef]

15. Wong, T.W.; Tam, W.; Yu, I.T.S.; Wun, Y.T.; Wong, A.H.S.; Wong, C.M. Association between air pollution and general practitioner visits for respiratory diseases in Hong Kong. Thorax 2006, 61, 585-591. [CrossRef] [PubMed] 
16. Parker, J.D.; Akinbami, L.J.; Woodruff, T.J. Air Pollution and Childhood Respiratory Allergies in the United States. Environ. Health Perspect. 2009, 117, 140-147. [CrossRef] [PubMed]

17. Vigotti, M.; Mataloni, F.; Bruni, A.; Minniti, C.; Gianicolo, E. Mortality analysis by neighbourhood in a city with high levels of industrial air pollution. Int. J. Public Health 2014, 59, 645-653. [CrossRef] [PubMed]

18. Weichenthal, S.; Kulka, R.; Dubeau, A.; Martin, C.; Wang, D.; Dales, R. Traffic-related air pollution and acute changes in heart rate variability and respiratory function in urban cyclists. Environ. Health Perspect. 2011, 119, 1373-1378. [CrossRef]

19. Yang, X.-Y.; Okada, Y.; Tang, N.; Matsunaga, S.; Tamura, K.; Lin, J.-M.; Kameda, T.; Toriba, A.; Hayakawa, K. Long-range transport of polycyclic aromatic hydrocarbons from China to Japan. Atmos. Environ. 2007, 41, 2710-2718. [CrossRef]

20. Tang, N.; Hattori, T.; Taga, R.; Igarashi, K.; Yang, X.; Tamura, K.; Kakimoto, H.; Mishukov, V.F.; Toriba, A.; Kizu, R.; et al. Polycyclic aromatic hydrocarbons and nitropolycyclic aromatic hydrocarbons in urban air particulates and their relationship to emission sources in the Pan-Japan Sea countries. Atmos. Environ. 2005, 39, 5817-5826. [CrossRef]

21. Tang, N.; Hakamata, M.; Sato, K.; Okada, Y.; Yang, X.; Tatematsu, M.; Toriba, A.; Kameda, T.; Hayakawa, K. Atmospheric behaviors of polycyclic aromatic hydrocarbons at a Japanese remote background site, Noto peninsula, from 2004 to 2014. Atmos. Environ. 2015, 120, 144-151. [CrossRef]

22. Tang, N.; Suzuki, G.; Morisaki, H.; Tokuda, T.; Yang, X.; Zhao, L.; Lin, J.; Kameda, T.; Toriba, A.; Hayakawa, K. Atmospheric behaviors of particulate-bound polycyclic aromatic hydrocarbons and nitropolycyclic aromatic hydrocarbons in Beijing, China from 2004 to 2010. Atmos. Environ. 2017, 152, 354-361. [CrossRef]

23. Ni, Z.; Luo, K.; Zhang, J.; Feng, R.; Zheng, H.; Zhu, H.; Wang, J.; Fan, J.; Gao, X.; Cen, K. Assessment of winter air pollution episodes using long-range transport modeling in Hangzhou, China, during World Internet Conference, 2015. Environ. Pollut. 2018, 236, 550-561. [CrossRef] [PubMed]

24. Kim, J.-S.; Park, K. Atmospheric aging of Asian dust particles during long range transport. Aerosol Sci. Technol. 2012, 46, 913-924. [CrossRef]

25. Jariyasopit, N.; Zimmermann, K.; Schrlau, J.; Arey, J.; Atkinson, R.; Yu, T.-W.; Dashwood, R.H.; Tao, S.; Simonich, S.L.M. Heterogeneous Reactions of Particulate Matter-Bound PAHs and NPAHs with $\mathrm{NO}_{3} / \mathrm{N}_{2} \mathrm{O}_{5}$, $\mathrm{OH}$ Radicals, and $\mathrm{O}_{3}$ under Simulated Long-Range Atmospheric Transport Conditions: Reactivity and Mutagenicity. Environ. Sci. Technol. 2014, 48, 10155-10164. [CrossRef] [PubMed]

26. Athanasopoulou, E.; Protonotariou, A.; Papangelis, G.; Tombrou, M.; Mihalopoulos, N.; Gerasopoulos, E. Long-range transport of Saharan dust and chemical transformations over the Eastern Mediterranean. Atmos. Environ. 2016, 140, 592-604. [CrossRef]

27. Tang, N.; Sato, K.; Tokuda, T.; Tatematsu, M.; Hama, H.; Suematsu, C.; Kameda, T.; Toriba, A.; Hayakawa, K. Factors affecting atmospheric 1-, 2-nitropyrenes and 2-nitrofluoranthene in winter at Noto peninsula, a remote background site, Japan. Chemosphere 2014, 107, 324-330. [CrossRef]

28. Yang, L.; Tang, N.; Matsuki, A.; Takami, A.; Hatakeyama, S.; Kaneyasu, N.; Nagato, E.G.; Sato, K.; Yoshino, A.; Hayakawa, K. A Comparison of Particulate-Bound Polycyclic Aromatic Hydrocarbons Long-Range Transported from the Asian Continent to the Noto Peninsula and Fukue Island, Japan. Asian J. Atmos. Environ. 2018, 12, 8. [CrossRef]

29. The Number of Population, Households (the Latest) | Wajima-shi. Available online: https:/translation1.j-server.com/LUCWAJIMA/ns/tl.cgi/https://www.city.wajima.ishikawa.jp/docs/ 2017050900011/?SLANG=ja\&TLANG=en\&XMODE=0\&XJSID=0 (accessed on 20 December 2019).

30. Japan Meteorological Agency. Download Past Weather Data. Available online: https://www.jma.go.jp/jma/ indexe.html (accessed on 20 December 2019).

31. Xu, Z.; Xue, L.; Wang, T.; Xia, T.; Gao, Y.; Louie, P.K.K.; Luk, C.W.Y. Measurements of Peroxyacetyl Nitrate at a Background Site in the Pearl River Delta Region: Production Efficiency and Regional Transport. Aerosol Air Qual. Res. 2015, 15, 833-841. [CrossRef]

32. Lhotka, R.; Pokorná, P.; Zíková, N. Long-Term Trends in PAH Concentrations and Sources at Rural Background Site in Central Europe. Atmosphere 2019, 10, 687. [CrossRef]

33. Manual for Continuous Monitoring of Air Pollution of Japan, Version 6.0. Available online: http://www.env. go.jp/air/osen/manual_6th/index.html (accessed on 20 December 2019). 
34. Manoli, E.; Kouras, A.; Karagkiozidou, O.; Argyropoulos, G.; Voutsa, D.; Samara, C. Polycyclic aromatic hydrocarbons (PAHs) at traffic and urban background sites of northern Greece: Source apportionment of ambient PAH levels and PAH-induced lung cancer risk. Environ. Sci. Pollut. Res. 2016, 23, 3556-3568. [CrossRef]

35. Zhu, Y.; Yang, L.; Yuan, Q.; Yan, C.; Dong, C.; Meng, C.; Sui, X.; Yao, L.; Yang, F.; Lu, Y.; et al. A Airborne particulate polycyclic aromatic hydrocarbon (PAH) pollution in a background site in the North China Plain: Concentration, size distribution, toxicity and sources. Sci. Total Environ. 2014, 466-467, 357-368. [CrossRef] [PubMed]

36. Kim, J.Y.; Lee, J.Y.; Choi, S.-D.; Kim, Y.P.; Ghim, Y.S. Gaseous and particulate polycyclic aromatic hydrocarbons at the Gosan background site in East Asia. Atmos. Environ. 2012, 49, 311-319. [CrossRef]

37. Vestenius, M.; Leppänen, S.; Anttila, P.; Kyllönen, K.; Hatakka, J.; Hellén, H.; Hyvärinen, A.-P.; Hakola, H. Background concentrations and source apportionment of polycyclic aromatic hydrocarbons in south-eastern Finland. Atmos. Environ. 2011, 45, 3391-3399. [CrossRef]

38. Ministry of the Environment_Air Pollution Status. Available online: http://www.env.go.jp/air/osen/index.html (accessed on 20 December 2019).

39. Feng, J.; Guo, Z.; Chan, C.K.; Fang, M. Properties of organic matter in $\mathrm{PM}_{2.5}$ at Changdao Island, China-A rural site in the transport path of the Asian continental outflow. Atmos. Environ. 2007, 41, 1924-1935. [CrossRef]

40. Zhang, Q.; Zheng, Y.X.; Tong, D.; Shao, M.; Wang, S.X.; Zhang, Y.H.; Xu, X.D.; Wang, J.N.; He, H.; Liu, W.Q.; et al. Drivers of improved $\mathrm{PM}_{2.5}$ air quality in China from 2013 to 2017. Proc. Natl. Acad. Sci. USA 2019, 116, 24463-24469. [CrossRef]

41. Onishi, K.; Otani, S.; Yoshida, A.; Mu, H.; Kurozawa, Y. Adverse Health Effects of Asian Dust Particles and Heavy Metals in Japan. Asia Pac. J. Public Health 2015, 27, NP1719-NP1726. [CrossRef]

42. Onishi, K.; Kurosaki, Y.; Otani, S.; Yoshida, A.; Sugimoto, N.; Kurozawa, Y. Atmospheric transport route determines components of Asian dust and health effects in Japan. Atmos. Environ. 2012, 49, 94-102. [CrossRef]

43. Lim, S.; Lee, M.; Lee, G.; Kim, S.; Yoon, S.; Kang, K. Ionic and carbonaceous compositions of $\mathrm{PM}_{10}, \mathrm{PM}_{2.5}$ and $\mathrm{PM}_{1.0}$ at Gosan ABC Superstation and their ratios as source signature. Atmos. Chem. Phys. 2012, 12, 2007-2024. [CrossRef]

44. Zhang, J.; Yang, L.; Mellouki, A.; Wen, L.; Yang, Y.; Gao, Y.; Jiang, P.; Li, Y.; Wang, W. Chemical characteristics and influence of continental outflow on $\mathrm{PM}_{1.0}, \mathrm{PM}_{2.5}$ and $\mathrm{PM}_{10}$ measured at Tuoji island in the Bohai Sea. Sci. Total Environ. 2016, 573, 699-706. [CrossRef]

45. Hu, S.; Polidori, A.; Arhami, M. Redox activity and chemical speciation of size fractioned PM in the communities of the Los Angeles-Long Beach harbor. Atmos. Chem. Phys. 2008, 8, 6439-6451. [CrossRef]

46. Li, W.J.; Li, H.; Li, J.J.; Cheng, X.L.; Zhang, Z.Z.; Chai, F.H.; Zhang, H.; Yang, T.; Duan, P.L.; Lu, D.F.; et al. TOF-SIMS surface analysis of chemical components of size-fractioned urban aerosols in a typical heavy air pollution event in Beijing. J. Environ. Sci. 2018, 69, 61-76. [CrossRef] [PubMed]

47. Turpin, B.J.; Huntzicker, J.J. Identification of secondary organic aerosol episodes and quantitation of primary and secondary organic aerosol concentrations during SCAQS. Atmos. Environ. 1995, 29, 3527-3544. [CrossRef]

48. Cheng, M.-C.; You, C.-F.; Cao, J.; Jin, Z. Spatial and seasonal variability of water-soluble ions in PM 2.5 aerosols in 14 major cities in China. Atmos. Environ. 2012, 60, 182-192. [CrossRef]

49. Vingarzan, R. A review of surface ozone background levels and trends. Atmos. Environ. 2004, 38, 3431-3442. [CrossRef]

50. Necki, J.; Schmidt, M.; Rozanski, K.; Zimnoch, M.; Korus, A.; Lasa, J.; Graul, R.; Levin, I. Six-year record of atmospheric carbon dioxide and methane at a high-altitude mountain site in Poland. Tellus B Chem. Phys. Meteorol. 2003, 55, 94-104. [CrossRef]

51. Steinbrecher, R.; Klauer, M.; Hauff, K.; Stockwell, W.R.; Jaeschke, W.; Dietrich, T.; Herbert, F. Biogenic and anthropogenic fluxes of non-methane hydrocarbons over an urban-imapcted forest, Frankfurter Stadtwald, Germany. Atmos. Environ. 2000, 34, 3779-3788. [CrossRef]

52. Bidleman, T.F.; Billings, W.N.; Foreman, W.T. Vapor-particle partitioning of semivolatile organic compounds: Estimates from field collections. Environ. Sci. Technol. 1986, 20, 1038-1043. [CrossRef] 
53. Kong, S.; Ding, X.; Bai, Z.; Han, B.; Chen, L.; Shi, J.; Li, Z. A seasonal study of polycyclic aromatic hydrocarbons in $\mathrm{PM}_{2.5}$ and $\mathrm{PM}_{2.5-10}$ in five typical cities of Liaoning Province, China. J. Hazard. Mater. 2010, 183, 70-80. [CrossRef]

54. Zhang, L.L.; Yang, L.; Zhou, Q.Y.; Zhang, X.; Xing, W.L.; Wei, Y.J.; Hu, M.; Zhao, L.X.; Toriba, A.; Hayakawa, K.; et al. Size distribution of particulate polycyclic aromatic hydrocarbons in fresh combustion smoke and ambient air: A review. J. Environ. Sci. 2020, 88, 370-384. [CrossRef]

55. Hong, H.; Yin, H.; Wang, X.; Ye, C. Seasonal variation of PM10-bound PAHs in the atmosphere of Xiamen, China. Atmos. Res. 2007, 85, 429-441. [CrossRef]

56. Yang, L.; Suzuki, G.; Zhang, L.L.; Zhou, Q.Y.; Zhang, X.; Xing, W.L.; Shima, M.; Yoda, Y.; Nakatsubo, R.; Hiraki, T.; et al. The Characteristics of Polycyclic Aromatic Hydrocarbons in Different Emission Source Areas in Shenyang, China. Int. J. Environ. Res. Public. Health 2019, 16, 2817. [CrossRef] [PubMed]

57. De La Torre-Roche, R.J.; Lee, W.-Y.; Campos-Díaz, S.I. Soil-borne polycyclic aromatic hydrocarbons in El Paso, Texas: Analysis of a potential problem in the United States/Mexico border region. J. Hazard. Mater. 2009, 163, 946-958. [CrossRef] [PubMed]

58. Yunker, M.B.; Macdonald, R.W.; Vingarzan, R.; Mitchell, R.H.; Goyette, D.; Sylvestre, S. PAHs in the Fraser River basin: A critical appraisal of PAH ratios as indicators of PAH source and composition. Org. Geochem. 2002, 33, 489-515. [CrossRef]

59. Ojeda-Castillo, V.; López-López, A.; Hernández-Mena, L.; Murillo-Tovar, M.A.; Díaz-Torres, J.D.J.; Hernández-Paniagua, I.Y.; Del Real-Olvera, J.; León-Becerril, E. Atmospheric Distribution of PAHs and Quinones in the Gas and PM1 Phases in the Guadalajara Metropolitan Area, Mexico: Sources and Health Risk. Atmosphere 2018, 9, 137. [CrossRef]

60. Tobiszewski, M.; Namieśnik, J. PAH diagnostic ratios for the identification of pollution emission sources. Environ. Pollut. 2012, 162, 110-119. [CrossRef] [PubMed]

61. Ravindra, K.; Sokhi, R.; Van Grieken, R. Atmospheric polycyclic aromatic hydrocarbons: Source attribution, emission factors and regulation. Atmos. Environ. 2008, 42, 2895-2921. [CrossRef]

62. Slezakova, K.; Pires, J.C.M.; Castro, D.; Alvim-Ferraz, M.C.M.; Delerue-Matos, C.; Morais, S.; Pereira, M.C. PAH air pollution at a Portuguese urban area: Carcinogenic risks and sources identification. Environ. Sci. Pollut. Res. 2013, 20, 3932-3945. [CrossRef]

63. Sadanaga, Y.; Ishiyama, A.; Takaji, R.; Matsuki, A.; Kato, S.; Sato, K.; Osada, K.; Bandow, H. Behavior of total peroxy and total organic nitrate concentrations at Suzu on the Noto Peninsula, Japan: Long-range transport and local photochemical production. Atmos. Environ. 2019, 196, 20-26. [CrossRef] 